\title{
TEMPORAL AND SPATIAL VARIATIONS OF ATMOSPHERIC RADIOCARBON IN THE MEXICO CITY METROPOLITAN AREA
}

Laura Beramendi-Orosco ${ }^{1} \bullet$ Galia Gonzalez-Hernandez ${ }^{2}$ - Adriana Martinez-Jurado ${ }^{3} \bullet$

Angeles Martinez-Reyes ${ }^{3} \cdot$ Alfonso Garcia-Samano $^{4} \cdot$ Jose Villanueva-Diaz $^{5} \bullet$

Francisco Javier Santos-Arevalo ${ }^{6}$ Isabel Gomez-Martinez ${ }^{6} \cdot$ Omar Amador-Muñoz $^{7}$

\begin{abstract}
The Mexico City Metropolitan Area (MCMA) produces a complex mixture of gases and aerosols from diverse sources, including burning of fossil fuels, biomass, and wastes, with a significant biogenic contribution. We present the first results of ongoing projects to study temporal and spatial variations of ${ }^{14} \mathrm{CO}_{2}$ in the area. Temporal variations reconstructed from tree rings of Taxodium mucronatum indicate a considerable radiocarbon depletion, in accordance to the vast amount of fossil fuels burnt inside Mexico Valley, with values between 62 and 246\% lower than background values for the 1962-1968 period, and lower by $51-88 \%$ for the $1983-2010$ period. The lower dilution found for the last decades might indicate an increase in enriched ${ }^{14} \mathrm{CO}_{2}$ sources. Results from the spatial distribution, as revealed from integrated $\mathrm{CO}_{2}$ samples and grasses from six points within the MCMA collected during the 2013 dry season, show variations between sites and sample types. For integrated $\mathrm{CO}_{2}$ samples, values range from $35.6 \%$ to $54.0 \%$, and for grasses between $-86.8 \%$ and $40.7 \%$. For three of the sampling points, the grasses are significantly depleted, by up to $\sim 133 \%$, as compared to the corresponding integrated $\mathrm{CO}_{2}$ sample. This may result from differences in the carbon assimilation period and exposure to different $\mathrm{CO}_{2}$ sources. Higher-than-background $\Delta^{14} \mathrm{C}$ values were found for all integrated $\mathrm{CO}_{2}$ samples, presumably resulting from ${ }^{14} \mathrm{C}$-enriched $\mathrm{CO}_{2}$ derived from forest fires in the mountains during the sampling period. Results obtained so far confirm the complexity of the ${ }^{14} \mathrm{C}$ cycle in the MCMA.
\end{abstract}

\section{INTRODUCTION}

Radiocarbon in atmospheric $\mathrm{CO}_{2}\left({ }^{14} \mathrm{CO}_{2}\right)$ from urban environments has been used as a direct tracer for fossil-fuel-derived $\mathrm{CO}_{2}$ to estimate anthropogenic emissions. Because fossil fuels are ${ }^{14} \mathrm{C}$-free as a result of their age of several million years, the increase in fossil $\mathrm{CO}_{2}$ emissions has altered the carbon isotopic composition of the atmosphere, more notably in urban and industrial areas, where the ${ }^{14} \mathrm{CO}_{2}$ concentration can be significantly lower than in clean (background) areas (Levin et al. 2003; Turnbull et al. 2006). This approach has been successfully applied for cities in Europe, Asia, and North America with fossil fuel burning as the major source of anthropogenic $\mathrm{CO}_{2}$, by monitoring atmospheric ${ }^{14} \mathrm{CO}_{2}$ (e.g. Takahashi et al. 2002; Turnbull et al. 2006; Kuc et al. 2007; Levin et al. 2008; Molnár et al. 2010; Zhou et al. 2014). Another important anthropogenic perturbation to atmospheric ${ }^{14} \mathrm{C}$ levels was its significant increase, up to twice the natural levels, derived from the atmospheric nuclear tests performed during the 1950s and 1960s. After the Nuclear Test Ban treaty, signed in October $1963,{ }^{14} \mathrm{CO}_{2}$ concentration started to decrease due to carbon exchange with other reservoirs, mainly the biosphere and oceans, and the important increase in anthropogenic fossil $\mathrm{CO}_{2}$ emissions in the last 4 decades. The pulsed input of excess ${ }^{14} \mathrm{C}$ makes it a potential tracer to study the carbon dynamics between and within the different reservoirs of the carbon cycle (Levin and Hesshaimer 2000), with the possibility of reconstructing ${ }^{14} \mathrm{C}$ levels, with annual resolution, from tree rings (Hua and Barbetti 2004).

Mexico City and its metropolitan area (MCMA) comprise the biggest megacity in North America. The MCMA is located in a high-altitude ( $2300 \mathrm{~m}$ asl) closed basin surrounded by mountains and

1. Instituto de Geologia, Universidad Nacional Autonoma de Mexico, Ciudad Universitaria, 04510, Mexico. Corresponding author. Email: laurab@geologia.unam.mx.

2. Instituto de Geofisica, Universidad Nacional Autonoma de Mexico, Ciudad Universitaria, 04510, Mexico

3. Posgrado en Ciencias Biológicas, Universidad Nacional Autonoma de Mexico, Ciudad Universitaria, 04510, Mexico.

4. Facultad de Ciencias, Universidad Nacional Autonoma de Mexico, Ciudad Universitaria, 04510, Mexico.

5. Laboratorio Nacional de Dendrocronologia, Instituto Nacional de Investigaciones Forestales Agricolas y Pecuarias, Gomez Palacio, Durango, Apdo Postal 41, Mexico.

6. Centro Nacional de Aceleradores (CNA), Avda. Thomas Alva Edison 7, Isla de la Cartuja, Seville 41092, Spain.

7. Centro de Ciencias de la Atmosfera, Universidad Nacional Autonoma de Mexico, Ciudad Universitaria, 04510 , Mexico.

Proceedings of the 1st International Radiocarbon in the Environment Conference 18-22 August 2014, Queen's University Belfast, Belfast, Northern Ireland, UK

Edited by Evelyn Keaveney and Paula Reimer 
one active volcano (Popocatepetl, in the eastern MCMA). There are more than 20 million inhabitants, around 30,000 manufacturing industries, and 5.9 million vehicles. Despite being such a big megalopolis, only $65 \%$ of the area classifies as urban soil, and the rest corresponds to rural, forest, and shrub-lands (INEGI 2014; SEDEMA 2013). A result of this complexity is the emission of high levels of a complex mixture of gases and aerosols from diverse sources, including burning of fossil fuels, biomass, and wastes, with a significant biogenic contribution. According to the Metropolitan Environmental Commission of Mexico Valley (CAM), the mean daily consumption of energy during 2012 was equivalent to 47 million liters of gasoline, distributed as $44 \%$ gasoline, $25 \%$ natural gas, $18 \%$ liquefied petroleum gas (LPG), and $13 \%$ diesel. The consumption by sector was $59 \%$ for transport, $25 \%$ for industrial activities, $13 \%$ for residential combustion, and 3\% for other sources including forest fires, gas storage, and landfills (SEDEMA 2013).

Considering the vast amount of fossil fuels consumed in the area, it would be expected to find a significant ${ }^{14} \mathrm{C}$ dilution in the local atmosphere; however, a previous study reported anomalous high levels of atmospheric ${ }^{14} \mathrm{CO}_{2}$ (Vay et al. 2009). In 2006, MCMA and surroundings were the scope of the multinational MILAGRO campaign (Megacity Initiative: Local and Global Research Observations) with the aim of characterizing the sources and processes of emissions as well as to evaluate the impact at regional and global scales (Molina et al. 2010). In this framework, Vay et al. (2009) reported that only $23 \%$ of instantaneous air samples had ${ }^{14} \mathrm{CO}_{2}$ levels below the free tropospheric background value $(57 \pm 2 \%$, estimated from the INTEX-B transit flight data obtained over the North Pacific for April 2006), indicating a dilution resulting from the addition of fossil $\mathrm{CO}_{2}$ $\left({ }^{14} \mathrm{C}\right.$-free) to the local atmosphere. Surprisingly, the rest of the samples had values up to $75 \%$ higher than the background values reported for North America, indicating an important contribution from ${ }^{14} \mathrm{C}$-enriched $\mathrm{CO}_{2}$ sources, such as burning of biomass with a mean age of $35 \mathrm{yr}$ and $\Delta^{14} \mathrm{C}$ of around $500 \%$, or even other hotter sources including burning of radioactive wastes (Vay et al. 2009).

Biomass burning as a source of $\mathrm{CO}_{2}$ in the MCMA is further supported by previous works reporting the presence of retene (1-methyl-7-isopropyl phenanthrene) in the southwestern MCMA (Bravo et al. 2006; Amador-Muñoz et al. 2013). Retene is a polycyclic aromatic hydrocarbon marker of softwood combustion generated from the burning of vegetation (Ramdahl 1983). High concentrations have been reported for the dry warm season (March-April), with especially high levels in 1998 due to the presence of many fires around the valley caused by severe dry conditions associated with the El Niño phenomenon (Amador-Muñoz et al. 2013). Up to $40 \%$ of the total seasonal variability in rainfall for Mexico may be explained by the El Niño-Southern Oscillation (ENSO) (Magaña et al. 2003).

With the aim of gaining a better understanding of the ${ }^{14} \mathrm{C}$ cycle in such a complex area, we are conducting three projects to establish temporal and spatial variations of ${ }^{14} \mathrm{CO}_{2}$ as revealed from tree rings, grasses, and integrated $\mathrm{CO}_{2}$ samples. This article presents the first results of annual variations reconstructed from annual growth rings of Taxodium mucronatum sampled in the central area of MCMA, and results of a study of the spatial variations, as revealed from integrated $\mathrm{CO}_{2}$ and grasses at six points with different traffic regimes, population density, and $\mathrm{CO}_{2}$ sources with a seasonal resolution since April 2013.

\section{METHODOLOGY}

\section{Study Area}

The MCMA is located in a high-altitude ( $2300 \mathrm{~m}$ asl) volcano-tectonic basin, surrounded by mountains to the south, east, and west, and almost completely open on the north side. It comprises Mexico City and 88 municipalities, covering an area of about $1800 \mathrm{~km}^{2}$. The MCMA can be divided into urban areas $(65.5 \%)$ and conservation areas $(34.5 \%$, including rural soils, forests, and shrub- 
lands). The industrial activity is mainly concentrated in the northern and eastern parts of Mexico City, mixed with highly populated areas. The central, southern, and western zones are dominated by residential, commercial, and conservation areas (SEDEMA 2013).

The Mexico City Basin is located in tropical-subtropical latitudes $\left(19^{\circ} 36^{\prime}\right.$ to $\left.19^{\circ} 20^{\prime} \mathrm{N}\right)$ with climate tempered by altitude and influenced by tropical air masses during summer (May to October) and mid-latitude cold air masses from North America during winter (Jauregui 2004). The mean annual temperature is $16^{\circ} \mathrm{C}$ and the annual precipitation, concentrated in summer months, is $400-500 \mathrm{~mm}$ in the northern part of the basin and 700-1200 mm in the central and southern parts (Jauregui 2004; INEGI 2014).

The population has grown considerably in the last decades, though since 1990, the growth has been mainly in the metropolitan area. In 1950, there were around 3 million inhabitants in Mexico City, with the metropolitan area dominated by small rural communities. In 1970, there were 6.87 million inhabitants in Mexico City and 2.19 million in the metropolitan area; by contrast, in 2010, Mexico City had around 8.85 million inhabitants, whereas the metropolitan area had more than 11.7 million inhabitants (Escamilla-Herrera and Santos-Cerquera 2012; INEGI 2014).

\section{Sampling and Sample Preparation}

Tree Rings

The sampling site for the annual reconstruction was Chapultepec Forest, the largest park in the MCMA. It is an urban forest located in northwest Mexico City in the downtown district (from $19^{\circ} 23^{\prime} 40^{\prime \prime}$ to $19^{\circ} 25^{\prime} 45^{\prime \prime} \mathrm{N}$ and $99^{\circ} 10^{\prime} 40^{\prime \prime}$ to $99^{\circ} 14^{\prime} 15^{\prime \prime} \mathrm{W}$ ). This sampling site was selected because this location has been inside the urban area for centuries and a master dendrochronology has been previously reported (Villanueva-Diaz et al. 2003). Three specimens of Taxodium mucronatum, the most common native species present in this park, were sampled using a 12-mm Pressler incremental borer at about $1.5 \mathrm{~m}$ height, taking three ring cores from each tree. To establish the ${ }^{14} \mathrm{C}$ background values for Mexico City's latitude, a tree of the same species was sampled in the same way at Barranca de Amealco $\left(20^{\circ} 21^{\prime} 50^{\prime \prime} \mathrm{N}, 100^{\circ} 06^{\prime} 22^{\prime \prime} \mathrm{W}\right)$, a steep gorge located in an uncontaminated area away from the influence of urban areas, $140 \mathrm{~km}$ to the NW from Mexico City. This site was selected because a T. mucronatum master dendrochronology has already been reported (Stahle et al. 2011).

Samples were dried for $48 \mathrm{hr}$ at $60^{\circ} \mathrm{C}$, mounted on wooded core mounts, and sanded with increasing grit number sandpaper (400-1500) to expose cell structures. To avoid cross-ring contamination, the generated dust was removed with a brush and vacuum. The annual rings were counted under stereoscopic microscopes and the chronologies were established by comparison with the master dendrochronologies already reported for this species in both sampling sites (Villanueva et al. 2003; Stahle et al. 2011).

\section{Integrated Atmospheric $\mathrm{CO}_{2}$}

Sampling points correspond to five stations of the Atmospheric Monitoring Network of Mexico City's environmental authority (SIMAT in Spanish), where criteria pollutants $\left(\mathrm{CO}, \mathrm{NO}_{\mathrm{X}}, \mathrm{O}_{3}, \mathrm{SO}_{2}\right.$, $\mathrm{PM}_{2.5}, \mathrm{PM}_{10}$ ) have been monitored since the late 1980s. Meteorological parameters (temperature, pressure, relative humidity, and wind speed and direction) are also monitored at some of the stations. The five stations (out of 44 in the network) were selected as representative of the different areas of the valley, with diverse traffic regimes, commercial activities, population density, and $\mathrm{CO}_{2}$ sources and wind regimes (Figures 1, 2; Table 1). Tlalnepantla (referred to as NW) is located to the northwest in a mainly industrial area; San Agustín (referred to as NE) is located to the northeast and characterized as an industrial and densely populated area; Merced (referred to as C), located in the central district 
(a)

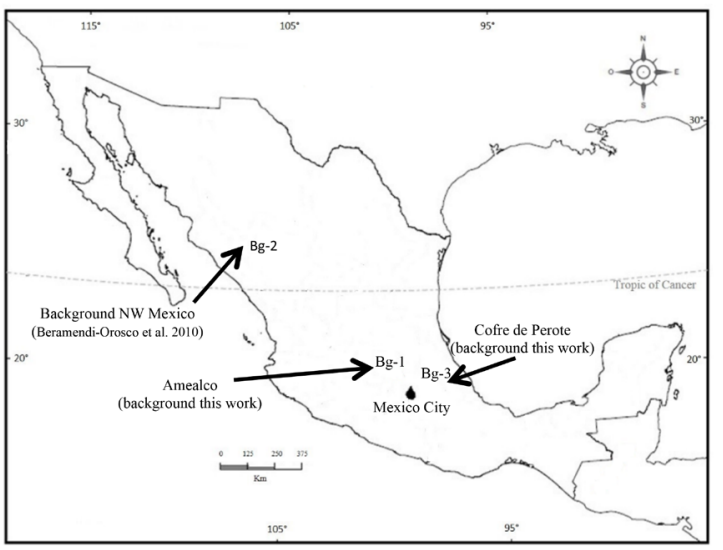

(b)

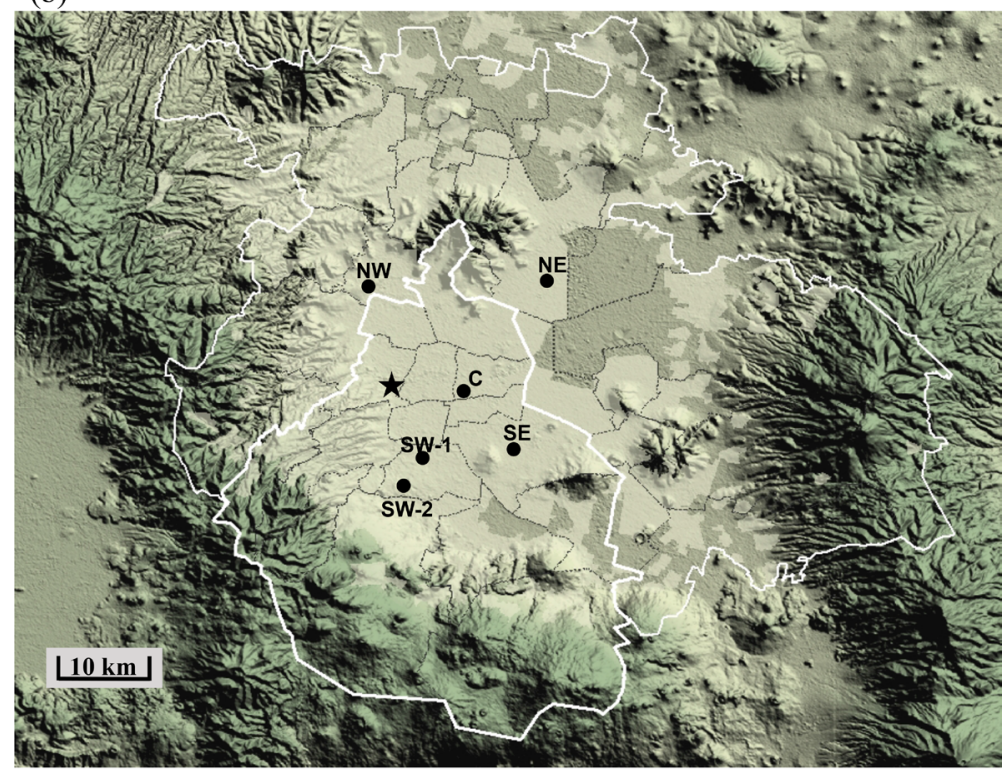

Figure 1 (a) Map of Mexico showing location of Mexico City (black dot) and the background sampling sites. (b) Map of MCMA showing sampling sites for tree-ring samples (black star) and for $\mathrm{CO}_{2}$ and grass samples (black circles). Maps modified from INEGI (http://cuentame. inegi.org.mx/mapas/).

of Mexico City, represents a commercial and residential area; Coyoacán in southwest Mexico City (referred to as SW-1) is located in a residential area with lower population density; and Iztapalapa (referred to as SE) is located inside the campus of the Universidad Autónoma Metropolitana in an industrial, commercial, and residential area. The sixth sampling point corresponds to the rooftop of a 3 -story building inside the main campus of the Universidad Nacional Autónoma de México (referred to as SW-2) located at the southern end of the urban area of Mexico City, adjacent to the place where a monthly ${ }^{13} \mathrm{CO}_{2}$ and ${ }^{14} \mathrm{CO}_{2}$ monitoring program has been performed by our research group since 2009 .

Integrated samples were collected by pumping air $\left(20 \mathrm{~mL} \mathrm{~min}^{-1}\right)$ continuously through a column with $1 \mathrm{~L}$ of a $0.7 \mathrm{M} \mathrm{NaOH}$ solution (carbonate-free, Sigma-Aldrich Mexico) for 30 days, at a height between 4 and $10 \mathrm{~m}$ from ground level. Immediately after sampling, $\mathrm{CO}_{3}{ }^{2-}$ was precipitated as $\mathrm{BaCO}_{3}$ by adding an excess of $\mathrm{BaCl}_{2}$, dried at $50^{\circ} \mathrm{C}$, and stored in glass flasks inside a vacuum desiccator until analysis. The sampling procedure was adapted from Levin et al. (1980) and Povinec et al. (1986), setting the flow rate of air through the $\mathrm{NaOH}$ solution after potentiometric titration of the final solution, in order to have an excess of $\mathrm{OH}^{-}$anions to guarantee a quantitative $\mathrm{CO}_{2}$ retention. 

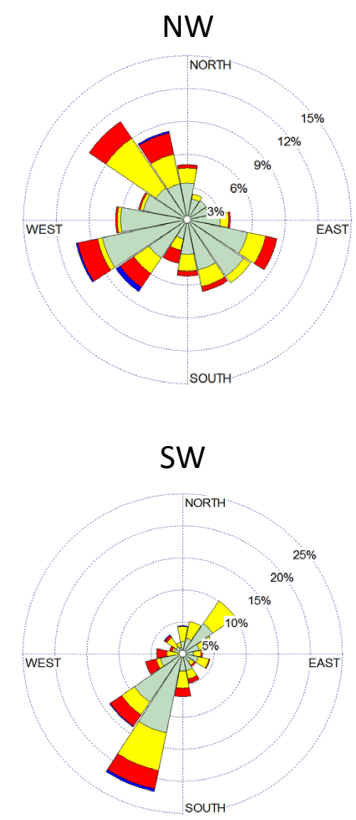
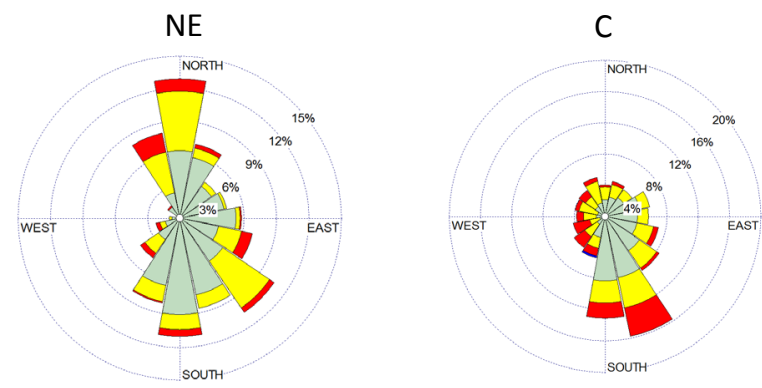

\section{$\mathrm{E}$}

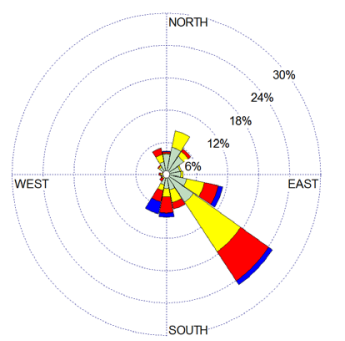

$\underset{(\mathrm{m} / \mathrm{s})}{W \mathrm{~N}}$

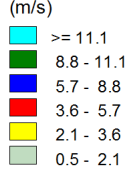

Figure 2 Wind roses for the sampling period (5 April-6 May 2013) with data registered at SIMAT stations Tlalnepantla (NW), San Agustín (NE), Merced (C), Pedregal (SW, nearest meteorological station to SW-2 and SW-1 sampling points), and Nezahualcóyotl (E, nearest meteorological station to SE sampling point). Calm wind conditions (wind speed $<0.5 \mathrm{~m} \mathrm{~s}^{-1}$ ) were lower than $3.54 \%$ of the sampled period. Data taken from SIMAT (http://www.aire.df.gob.mx/default.php?opc=\%27aKBhnmI=\%27\&opcion=Zw).

Table 1 Description of sampling sites within the MCMA.

\begin{tabular}{|c|c|c|c|}
\hline Site name & $\begin{array}{l}\text { Position within } \\
\text { MCMA }\end{array}$ & Coordinates & Main characteristics \\
\hline Tlalnepantla & Northwest, NW & $\begin{array}{l}19^{\circ} 31^{\prime} 42^{\prime \prime} \mathrm{N} \\
99^{\circ} 12^{\prime} 15^{\prime \prime} \mathrm{W}\end{array}$ & $\begin{array}{l}\text { Commercial/residential/industrial area. Medi- } \\
\text { um traffic. }\end{array}$ \\
\hline San Agustín & Northeast, NE & $\begin{array}{l}19^{\circ} 31^{\prime} 56^{\prime \prime} \mathrm{N}, \\
99^{\circ} 01^{\prime} 48^{\prime \prime} \mathrm{W}\end{array}$ & $\begin{array}{l}\text { Commercial/residential/industrial area. High } \\
\text { traffic. }\end{array}$ \\
\hline Merced & Central, C & $\begin{array}{l}19^{\circ} 25^{\prime} 28^{\prime \prime} \mathrm{N} \\
99^{\circ} 07^{\prime} 09^{\prime \prime} \mathrm{W}\end{array}$ & Commercial/residential area. High traffic. \\
\hline Iztapalapa & Southeast, SE & $\begin{array}{l}19^{\circ} 21^{\prime} 45^{\prime \prime} \mathrm{N}, \\
99^{\circ} 04^{\prime} 16^{\prime \prime} \mathrm{W}\end{array}$ & $\begin{array}{l}\text { Universidad Autónoma Metropolitana } \\
\text { Commercial/industrial area. High traffic. }\end{array}$ \\
\hline Coyoacán & Southwest, SW-1 & $\begin{array}{l}19^{\circ} 20^{\prime} 58^{\prime \prime} \mathrm{N} \\
99^{\circ} 09^{\prime} 26^{\prime \prime} \mathrm{W}\end{array}$ & Commercial/residential area. Medium traffic. \\
\hline UNAM & Southwest, SW-2 & $\begin{array}{l}19^{\circ} 19^{\prime} 19^{\prime \prime} \mathrm{N} \\
99^{\circ} 10^{\prime} 37^{\prime \prime} \mathrm{W}\end{array}$ & $\begin{array}{l}\text { Surrounded by buildings and ecological re- } \\
\text { serve. Commercial/residential areas nearby. } \\
\text { Medium traffic. }\end{array}$ \\
\hline
\end{tabular}

${ }^{\mathrm{a} I n f o r m a t i o n ~ t a k e n ~ f r o m ~ I N E C C ~(2012) . ~}$

\section{Grass Samples}

Grasses that were already growing close to the sampling stations at ground level (except for NW) were trimmed with stainless steel scissors the same day the atmospheric $\mathrm{CO}_{2}$ capture systems were installed, leaving $1.5 \mathrm{~cm}$ for regrowth. Sampling was performed on the same day the $\mathrm{CO}_{2}$ capture 
systems were removed. In this way, the sampled grasses fixed $\mathrm{C}$ during the same $\mathrm{CO}_{2}$ sampling period. At the NW sampling point, it was not possible to obtain a grass sample. Immediately after trimming, samples were packed in aluminum foil and, once in the laboratory, were washed with deionized water, dried at $50^{\circ} \mathrm{C}$, and stored in aluminum foil until analysis. Sampled species, identified by a botanical expert at the Faculty of Sciences-UNAM, were Cynodon dactilon $\left(\mathrm{C}_{4}\right.$ metabolism species) in NE; Bromus catharticus $\left(\mathrm{C}_{3}\right.$ species) in $\mathrm{C}$; Pennisetum clandestinum $\left(\mathrm{C}_{4}\right.$ species) in SW-1 and SE; and Bouteloua gracilis $\left(\mathrm{C}_{4}\right.$ species) in SW-2. We acknowledge that sampling different grass species makes the interpretation of the $\Delta^{14} \mathrm{C}$ data a difficult task, as differences in $\mathrm{CO}_{2}$ uptake and growth can result in $\Delta^{14} \mathrm{C}$ significantly different between plants growing at the same conditions, and thus could be misinterpreted as different contribution of fossil $\mathrm{CO}_{2}$ (Bozhinova et al. 2013).

\section{Annual Plants}

To establish a ${ }^{14} \mathrm{C}$ background for 2013, leaves from annual plants (Senecio cinerariodes and Lupinus montanus) were sampled during May 2013 at Cofre de Perote Mountain $\left(19^{\circ} 29^{\prime} 30^{\prime \prime} \mathrm{N}, 97^{\circ} 09^{\prime} 13^{\prime \prime} \mathrm{W}\right)$, $\sim 200 \mathrm{~km}$ away from the MCMA. Leaves were collected with stainless steel scissors and packed in aluminum foil. Once in the laboratory, samples were washed with deionized water, dried at $50^{\circ} \mathrm{C}$, and stored in aluminum foil until analysis. These samples were used as the background for 2013 as the tree-ring sequence from the other background site (Amealco) did not cover this year, and it was not possible to organize a field trip to Amealco during 2013. Despite its different location and that care should be taken with the interpretation of $\Delta^{14} \mathrm{C}$ from annual plants, in terms of different plant parts and growth periods (Bozhinova et al. 2013; Turnbull et al. 2014), this sample was analyzed to provide a reference value for the ${ }^{14} \mathrm{C}$ levels in clean air, as it has been demonstrated that the gradient in background ${ }^{14} \mathrm{C}$ distribution is only a few per mil (Levin et al. 2010; Graven et al. 2012).

\section{Sample Analysis}

\section{Tree Rings}

Individual tree rings were analyzed by accelerator mass spectrometry (AMS) at the Centro Nacional de Aceleradores (CNA), Seville, Spain. Prior to measurement, previously cleaned samples were graphitized using the AGE system (Wacker et al. 2010a). This system couples an elemental analyzer (EA) to the graphitization unit. Approximately $3 \mathrm{mg}$ of wood was wrapped in tin foil and loaded in the EA, where it was combusted. The columns inside the EA separate the gases produced in the combustion, loading the reactor of the graphitization unit with the $\mathrm{CO}_{2}$, and releasing to air the other components. $\mathrm{H}_{2}$ is added to the reactor with $\mathrm{Fe}$ used as a catalyst to reduce $\mathrm{CO}_{2}$ to graphite. Ovens are used to heat the part of the reactor where the reducing reaction takes place, and Peltier coolers are used to freeze the water produced in the reaction. The system prepares samples of $\sim 1 \mathrm{mg} \mathrm{C}$, and allows the preparation of seven samples in parallel, fully automatized.

Once graphitized, samples were measured in the MICADAS system (Synal et al. 2007). This ${ }^{14} \mathrm{C}$ detection system works at $200 \mathrm{kV}$ and selects charge state $1+$ after the stripping process for a total ion energy of $440 \mathrm{keV}$. Ions are counted in an ionization chamber. The major interference in the identification of ${ }^{14} \mathrm{C}$ is the molecular fragment ${ }^{13} \mathrm{C}$ coming from the ${ }^{13} \mathrm{CH}$ molecule. A special Faraday cup measures the current of this molecular fragment at the high-energy side and the number of counts in the detector is corrected correspondingly. $\delta^{13} \mathrm{C}$ is measured simultaneously in the graphite for a proper correction of the results.

Samples were measured for $1 \mathrm{hr}$ and data were analyzed using the BATS software (Wacker et al. 2010b). Oxalic acid II (SRM 4990C) was used as the normalization standard. The mean analytical 
relative uncertainty of the reported data was $0.42 \%$. The ${ }^{14} \mathrm{C}$ results are reported as $\mathrm{F}^{14} \mathrm{C}$ and $\Delta^{14} \mathrm{C}$ corrected for both isotopic fractionation and decay (Stuiver and Polach 1977; Reimer et al. 2004).

Integrated Atmospheric $\mathrm{CO}_{2}$, Grass, and Plant Samples

${ }^{14} \mathrm{C}$ analyses were performed at the Radiocarbon Laboratory at the National Autonomous University of Mexico (UNAM), by ultra-low-level liquid scintillation spectrometry. Prior to analysis, clean samples were transformed to benzene $(1.5 \mathrm{~mL})$ in a vacuum synthesis line and mixed with $0.5 \mathrm{~mL}$ of scintillation cocktail (PPO + POPOP dissolved in dead spectrophotometric-grade benzene) in 3 -mL Teflon ${ }^{\circledR}$ vials. Analyses were performed in a Quantulus ${ }^{\mathrm{TM}} 1220$ ultra-low-level liquid scintillation spectrometer as detailed in Beramendi-Orosco et al. (2006). Each sample was analyzed for 2500 min distributed in 50 cycles, alternating sample vials with oxalic acid II (SRM 4990C) standard and background vials. The counting window was set to optimize the figure of merit [defined as the ratio (counting efficiency) $/$ background], with a ${ }^{14} \mathrm{C}$ counting efficiency higher than $65 \%$ and the background less than 0.2 counts per minute $\mathrm{g}^{-1} \mathrm{C}$. The ${ }^{14} \mathrm{C}$ results are reported as $\mathrm{F}^{14} \mathrm{C}$ and $\Delta^{14} \mathrm{C}$ corrected for both isotopic fractionation and decay (Stuiver and Polach 1977; Reimer et al. 2004).

To correct $\Delta{ }^{14} \mathrm{C}$ values for isotopic fractionation, $\delta^{13} \mathrm{C}$ analyses were performed at the Laboratory of Stable Isotopes Spectrometry at the Institute of Geology UNAM. Results are reported as $\delta^{13} \mathrm{C}$ relative to the Vienna Pee-Dee Belemnite (VPDB) standard, with a precision of $0.2 \% 0$ and normalized with NIST and IAEA standard reference materials (NBS 22, PEF1, IAEA CH6, USGS 40, and USGS 41).

\section{RESULTS AND DISCUSSION}

\section{Tree Rings - Temporal Trend}

Results obtained so far for tree-ring samples from Chapultepec (urban) and Amealco (background) are presented in Table 2, and compared to reported background values in Figure $3 .{ }^{14} \mathrm{C}$ values obtained for Amealco are in agreement with previously reported background values for the Northern Hemisphere $(\mathrm{NH})$ zone 2, confirming that this area can be considered as background. When compared to the international curve for NH zone 2 (Hua et al. 2013), considered as the background values for the latitudes corresponding for all Mexico, the differences between the two data sets, for rings 1970-2007, are within $1 \sigma$, except for 2007, which is within $2 \sigma$. For the pre-1970 period, despite that only two samples have been analyzed, the difference between the data sets seems to be significant. For 1964, the difference is $\sim 70 \%$ as compared to the NH zone 2 curve, and $\sim 23 \%$ as compared to the previously reported data for NW Mexico (Beramendi-Orosco et al. 2010).

Values obtained for tree rings from Chapultepec (Mexico City) follow a similar increasing trend as the background values for the period 1953-1960, being closer to those reported for NW Mexico than to those of the NH zone 2 curve. For samples post-1962, the values obtained for tree rings from Chapultepec are significantly ${ }^{14} \mathrm{C}$ depleted with respect to all the background data sets, indicating a significant ${ }^{14} \mathrm{C}$ dilution by fossil $\mathrm{CO}_{2}$ in the urban atmosphere. This depletion was expected considering the vast amount of fossil fuels burned inside the valley; however, the magnitude of dilution seems bigger in the mid-1960s than in more recent decades. For years 1962.5-1965.5, the confidence intervals (95\% level) are lower than the confidence intervals for NH zone 2 by between 113 and 205\% ; whereas for years 1983.5, 1990.5, and 2010.5, the confidence intervals are lower than the NH zone 2 confidence intervals by 65,43 , and $37 \%$, respectively. This is somehow unexpected considering the significant growth in the consumption of fossil fuels associated with the increase in population and extension of MCMA since 1970, with a population increase from 9.06 million inhabitants in the valley to more than 20.55 inhabitants in 2010, and an increase of $245 \%$ in the number of registered vehicles from 1990 to 2010 (Escamilla-Herrera and Santos-Cerquera 2012; INEGI 2014). 


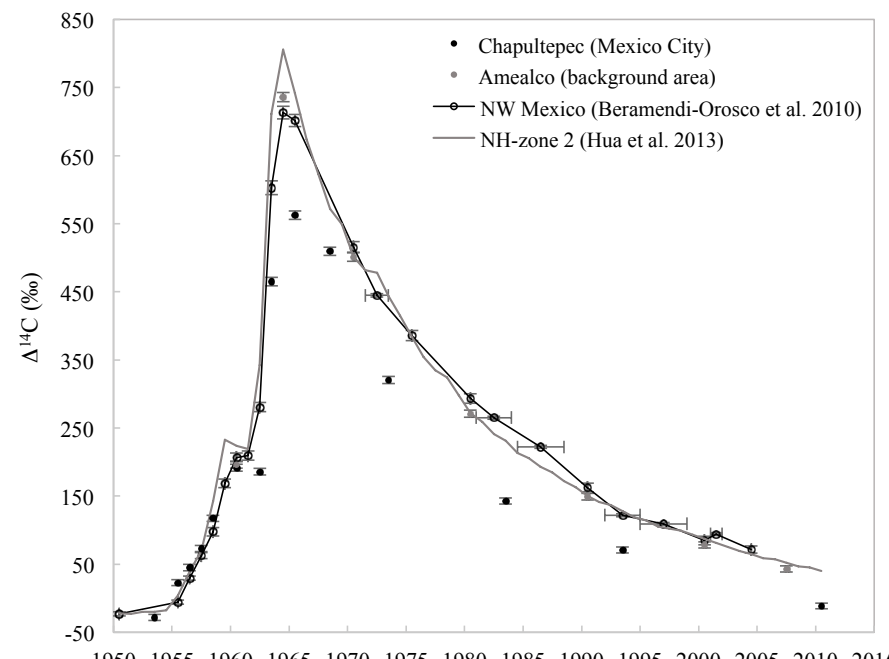

Figure $3 \Delta^{14} \mathrm{C}$ values for tree rings from Chapultepec Park, Mexico City (black circles), and tree rings from Amealco (background area, gray diamonds). Vertical error bars correspond to $\pm 1 \sigma$. Background values from NH zone 2 (Hua et al. 2013, gray line) and from tree rings from NW Mexico (Beramendi-Orosco et al. 2010, black line) are plotted for comparison. Horizontal error bars reflect the number of years comprising samples analyzed by liquid scintillation in the data set from NW Mexico.

Table $2 \mathrm{~F}^{14} \mathrm{C}$ and $\Delta^{14} \mathrm{C}$ values for tree-ring samples from Chapultepec Park in Mexico City and Amealco (background site).

\begin{tabular}{|c|c|c|c|c|}
\hline Sample code & Year & $\mathrm{F}^{14} \mathrm{C} \pm 1 \sigma$ & $\Delta^{14} \mathrm{C} \pm 1 \sigma(\%)$ & $\begin{array}{l}\text { Difference from mean } \\
\text { NH zone } 2(\%)\end{array}$ \\
\hline \multicolumn{5}{|c|}{ Chapultepec Park, Mexico City } \\
\hline CNA-2647.1.1 & 1953.5 & $0.9793 \pm 0.0044$ & $-28.3 \pm 4.3$ & -8 \\
\hline CNA-2645.1.1 & 1955.5 & $1.0311 \pm 0.0046$ & $23.1 \pm 4.5$ & 19 \\
\hline CNA-2644.1.1 & 1956.5 & $1.0531 \pm 0.0047$ & $45.0 \pm 4.6$ & 6 \\
\hline CNA-2646.1.1 & 1957.5 & $1.0813 \pm 0.0048$ & $73.0 \pm 4.8$ & 3 \\
\hline CNA-2814.1.1 & 1958.5 & $1.1258 \pm 0.0047$ & $117.2 \pm 4.7$ & -26 \\
\hline CNA-2643.1.1 & 1960.5 & $1.2011 \pm 0.0052$ & $191.8 \pm 5.2$ & -32 \\
\hline CNA-2813.1.1 & 1962.5 & $1.1949 \pm 0.0049$ & $185.7 \pm 4.9$ & -156 \\
\hline CNA-2642.1.1 & 1963.5 & $1.4765 \pm 0.0064$ & $465.1 \pm 6.3$ & -246 \\
\hline CNA-2815.1.1 & 1965.5 & $1.5749 \pm 0.0064$ & $562.7 \pm 6.4$ & -179 \\
\hline CNA-2816.1.1 & 1968.5 & $1.5213 \pm 0.0062$ & $509.6 \pm 6.2$ & -62 \\
\hline CNA-2641.1.1 & 1973.5 & $1.3306 \pm 0.0053$ & $320.3 \pm 5.3$ & -124 \\
\hline CNA-2640.1.1 & 1983.5 & $1.1518 \pm 0.0046$ & $142.9 \pm 4.6$ & -88 \\
\hline CNA-2638.1.1 & 1993.5 & $1.0791 \pm 0.0043$ & $70.8 \pm 4.3$ & -57 \\
\hline CNA-2638.1.1 & 2010.5 & $0.9962 \pm 0.0041$ & $-11.5 \pm 4.1$ & -51 \\
\hline \multicolumn{5}{|c|}{ Amealco (background) } \\
\hline CNA-2637.2.1 & 1960.5 & $1.2056 \pm 0.0052$ & $196.3 \pm 5.2$ & -28 \\
\hline CNA-2636.2.1 & 1964.5 & $1.7495 \pm 0.0071$ & $736.0 \pm 7.0$ & -70 \\
\hline CNA-2635.2.1 & 1970.5 & $1.5128 \pm 0.0063$ & $501.1 \pm 6.3$ & 0 \\
\hline CNA-2634.2.1 & 1980.5 & $1.2811 \pm 0.0055$ & $271.2 \pm 5.4$ & -1 \\
\hline CNA-2633.2.1 & 1990.5 & $1.1581 \pm 0.0050$ & $149.2 \pm 4.9$ & -1 \\
\hline CNA-2632.2.1 & 2000.5 & $1.0868 \pm 0.0048$ & $78.4 \pm 4.7$ & -9 \\
\hline CNA-2631.2.1 & 2007.5 & $1.0509 \pm 0.0046$ & $42.8 \pm 4.5$ & -9 \\
\hline
\end{tabular}


A possible explanation for the higher ${ }^{14} \mathrm{C}$ dilution in the 1960s than in the following 3 decades could be an increase in ${ }^{14} \mathrm{C}$-enriched $\mathrm{CO}_{2}$ emissions from biomass burning, deforestation, and land-use change associated with the growth of the urban area. Some other highly enriched sources, such as incineration of radioactive hospital wastes, cannot be ruled out. However, we consider that emissions from the nuclear power plant Laguna Verde, which began operations in 1990 and is located on the coast of the Gulf of Mexico, are unlikely because it is located $300 \mathrm{~km}$ to the east of Mexico City at sea level, with the Sierra Madre Oriental mountain range in between. Before estimating the annual variations of the concentration of fossil $\mathrm{CO}_{2}\left(\mathrm{C}_{\text {fossil }}\right)$ in the urban region, it is important to analyze both tree-ring sequences (Amealco and Chapultepec) with a higher resolution, as this background area seems to be more representative of the variation during the initial years of the ${ }^{14} \mathrm{C}$ bomb perturbation in the latitude corresponding to Mexico City, in agreement with the previously reported ${ }^{14} \mathrm{C}$ data for NW Mexico (Beramendi-Orosco et al. 2010).

\section{Integrated Atmospheric $\mathrm{CO}_{2}$ and Grasses - Spatial Variations}

Results for the integrated $\mathrm{CO}_{2}$ samples (six sampling points) and grasses (five sampling points) collected during April 2013 are plotted in Figure 4 and tabulated in Table 3. Results show variations, both between sites and between sample types. For integrated $\mathrm{CO}_{2}$ samples, $\Delta^{14} \mathrm{C}$ values range from $35.6 \%$ to $54.0 \%$. For grasses, the variation between sites is higher, with $\Delta{ }^{14} \mathrm{C}$ values ranging between $-86.82 \%$ and $40.71 \%$. For three of the sampling points, the grasses are significantly depleted, by up to $\sim 133 \%$, compared to the corresponding $\mathrm{CO}_{2}$ sample. For sampling points $\mathrm{SW}-1$ and $\mathrm{C}$, the values for both sample types are within $1 \sigma$ and $2 \sigma$, respectively. The big difference between the $\Delta{ }^{14} \mathrm{C}$ values recorded by the grass samples and the corresponding $\mathrm{CO}_{2}$ sample may be associated

\section{$\Delta{ }^{14} \mathrm{C}$ spatial variation}

(April 2013)

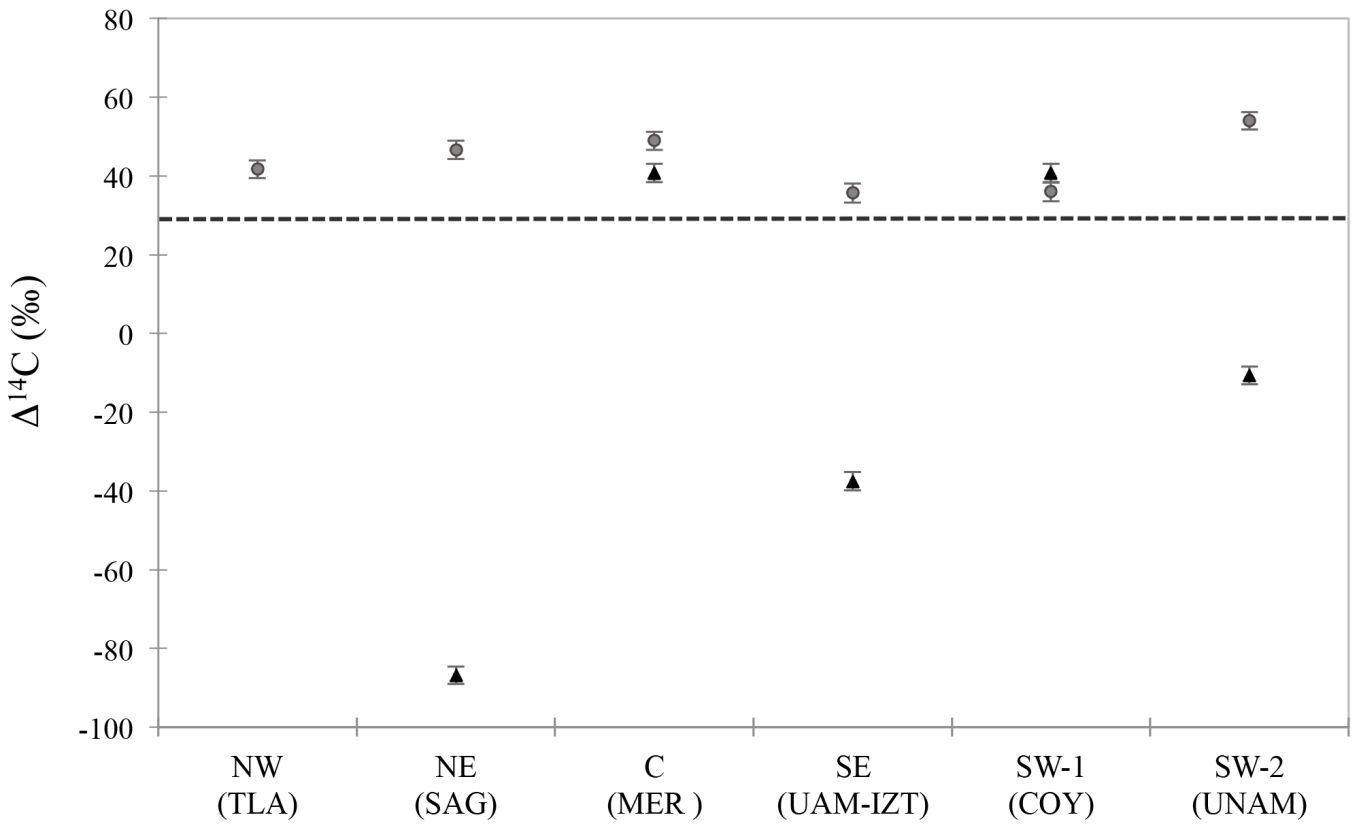

Figure $4 \quad \Delta^{14} \mathrm{C}$ values for integrated $\mathrm{CO}_{2}$ samples (gray circles) and grasses (black triangles) from six sampling points within Mexico City Metropolitan Area. Horizontal dotted line represents the mean $\Delta^{14} \mathrm{C}$ background value from annual plants collected at Cofre de Perote, located $200 \mathrm{~km}$ east of Mexico City (see text for details). 
with three factors. First, $\Delta^{14} \mathrm{C}$ values of grass samples correspond to daytime integrated samples, as $\mathrm{C}$ is fixed through photosynthesis. Second, $\Delta^{14} \mathrm{C}$ can be related to the residence time of $\mathrm{C}$ in grass, which could result in grass samples reflecting $\Delta^{14} \mathrm{C}$ values not representative of the same sampling period as the $\mathrm{CO}_{2}$ samples, which has been described as uncertainties in the $\mathrm{CO}_{2}$ assimilation period represented by the grass sample (Turnbull et al. 2014). The other factor may be the difference in sampling position and height; grass samples were collected at ground level in open spaces, some of them close to roads and exposed, almost directly, to fossil $\mathrm{CO}_{2}$ from vehicle exhaust; whereas $\mathrm{CO}_{2}$ samples were collected on rooftops between 4 and $10 \mathrm{~m}$ from ground level, suggesting that at these heights the $\mathrm{CO}_{2}$ from the different sources has mixed, and thus is more representative of the local atmosphere. The facts that for sampling sites SE and SW-1, with grass samples of the same species (Pennisetum clandestinum), there is a big difference $\left(74.14 \%\right.$ ) between the $\Delta^{14} \mathrm{C}$ values of the grass-integrated $\mathrm{CO}_{2}$ pair from SE, while $\Delta^{14} \mathrm{C}$ values for $\mathrm{SW}-1$ are statistically the same, suggesting that the position of the sample has a larger influence, at least for this grass species. The grass sample from the SW-1 site was collected inside an elementary school, in a courtyard behind a 4-story building approximately $50 \mathrm{~m}$ away from the road, whereas the grass sample from the SE site was collected $12 \mathrm{~m}$ away from the road in an open area.

Table 3 Radiocarbon levels for $\mathrm{CO}_{2}$ and grass samples collected at six points within the Mexico City Metropolitan Area.

\begin{tabular}{|c|c|c|c|c|c|c|}
\hline \multirow[b]{3}{*}{ Sampling period (2013) } & \multicolumn{6}{|c|}{ Sampling site } \\
\hline & $\begin{array}{l}\text { NW } \\
\text { (TLA) }\end{array}$ & $\begin{array}{l}\mathrm{NE} \\
(\mathrm{SAG}) \\
\end{array}$ & $\begin{array}{l}\mathrm{C} \\
(\mathrm{MER})\end{array}$ & $\begin{array}{l}\text { SE } \\
\text { (UAM-Izt) }\end{array}$ & $\begin{array}{l}\text { SW-1 } \\
\text { (COY) }\end{array}$ & $\begin{array}{l}\text { SW-2 } \\
\text { (UNAM) }\end{array}$ \\
\hline & 05/04-07/05 & 05/04-07/05 & 08/04-06/05 & 08/04-06/05 & 08/04-06/05 & 08/04-07/05 \\
\hline & \multicolumn{6}{|c|}{ Integrated $\mathrm{CO}_{2}$ samples } \\
\hline Sampling height (m) & 6 & 5 & 4 & 10 & 10 & 6 \\
\hline Sample code (UNAM-) & 1324 & 1325 & 1326 & 1328 & 1327 & 1329 \\
\hline$\delta^{13} \mathrm{C}(\% 0)^{\mathrm{a}}$ & -13.5 & -13.0 & -15.1 & -17.6 & -15.1 & -14.9 \\
\hline $\mathrm{F}^{14} \mathrm{C}^{\mathrm{b}}$ & 1.0498 & 1.0547 & 1.0571 & 1.0436 & 1.0439 & 1.0622 \\
\hline \multirow[t]{2}{*}{$\Delta^{14} \mathrm{C}(\%)^{\mathrm{c}}$} & 41.68 & 46.60 & 48.92 & 35.60 & 35.95 & 54.00 \\
\hline & \multicolumn{6}{|c|}{ Grass samples } \\
\hline Species & n.a. & $\begin{array}{l}\text { Cynodon } \\
\text { dactilon }\end{array}$ & $\begin{array}{l}\text { Bromus } \\
\text { catharticus }\end{array}$ & $\begin{array}{l}\text { Pennisetum } \\
\text { clandestinum }\end{array}$ & $\begin{array}{l}\text { Pennisetum } \\
\text { clandestinum }\end{array}$ & $\begin{array}{l}\text { Bouteloua } \\
\text { gracilis }\end{array}$ \\
\hline Sample code (UNAM-) & n.a. & 1356 & 1358 & 1353 & 1352 & 1331 \\
\hline$\delta^{13} \mathrm{C}(\% 0)^{\mathrm{a}}$ & n.a. & -17.7 & -27.2 & -14.1 & -14.4 & -15.6 \\
\hline $\mathrm{F}^{14} \mathrm{C}^{\mathrm{b}}$ & n.a. & 0.9203 & 1.0488 & 0.9699 & 1.0488 & 0.9970 \\
\hline$\Delta^{14} \mathrm{C}(\% 0)^{\mathrm{c}}$ & n.a. & -86.82 & 40.70 & -37.54 & 40.71 & -10.65 \\
\hline
\end{tabular}

${ }^{\mathrm{a}} \delta^{13} \mathrm{C}$ error $( \pm 1 \sigma)$ was $0.2 \%$.

${ }^{\mathrm{b}} \mathrm{F}^{14} \mathrm{C}$ error $( \pm 1 \sigma)$ was between 0.0022 and 0.0024 for all the samples.

${ }^{\mathrm{c}} \Delta^{14} \mathrm{C}$ error $( \pm 1 \sigma)$ was between $2.2 \%$ and $2.4 \%$ for all the samples.

Contrary to expectations, the $\Delta^{14} \mathrm{C}$ value for the $\mathrm{CO}_{2}$ sample from SW-1 is significantly lower $(95 \%$ confidence interval) than those found for samples from areas where the industrial and population densities are higher (NE, NW), suggesting that the fossil $\mathrm{CO}_{2}$ contribution is higher in SW-1, despite being characterized as a residential area with no industrial activities. Another relevant result is the fact that $\mathrm{CO}_{2}$ samples were ${ }^{14} \mathrm{C}$ enriched as compared to background values, estimated from $\Delta^{14} \mathrm{C}$ analyses of two annual plants, collected during May 2013 at Cofre de Perote Mountain $\left(19^{\circ} 29^{\prime} 30^{\prime \prime} \mathrm{N}, 97^{\circ} 09^{\prime} 13^{\prime \prime} \mathrm{W}\right.$ ), with values of $24.74 \pm 2.35 \%$ and $27.65 \pm 2.34 \%$ (mean $26.20 \%$, 
dotted line in Figure 4). This background value is in agreement with the values reported for the last months of 2012 for North America (between 25 and 32\%o, Niwot Ridge, Colorado; data from http:// www.esrl.noaa.gov/gmd/dv/iadv/). As mentioned in the Introduction, this is not the first time $\Delta^{14} \mathrm{C}$ values higher than background are found for atmospheric $\mathrm{CO}_{2}$ in Mexico City (Vay et al. 2009). This previous work reported values up to $75 \%$ higher than the background values, and attributed the ${ }^{14} \mathrm{C}$ enrichment mainly to $\mathrm{CO}_{2}$ emissions resulting from biomass burning, especially during the dry season, when forest fires are frequent (Vay et al. 2009).

A possible explanation for the high $\Delta^{14} \mathrm{C}$ values reported here for the integrated $\mathrm{CO}_{2}$ samples is also the occurrence of forest fires during the sampling period. According to the National Forestry Commission, there were 1157 fires in the mountains surrounding the valley between January and May 2013 (CONAFOR 2014), with four big forest fires during 13-14 April, two in the southern mountains, one in the mountains between the NW and NE sampling points, and the other fire in the western mountains. Although most of the fires affected mainly shrub-lands dominated by annual species (having a $\Delta^{14} \mathrm{C}$ value similar to that of the atmosphere), the organic matter in the burned topsoils, having an age of some decades, could be an enriched source of ${ }^{14} \mathrm{CO}_{2}$ to the atmosphere, with $\Delta \Delta^{14} \mathrm{C}$ values of up to $500-600 \%$. The enriched ${ }^{14} \mathrm{CO}_{2}$ produced in the mountains could be transported to the valley by the dominant wind directions (Figure 2), and mixed, at heights were integrated samples were taken, with the $\mathrm{CO}_{2}$ from the different sources (mainly respiration, fossil fuels, wastes, and biomass incineration), canceling out the ${ }^{14} \mathrm{C}$ dilution resulting from the vast amount of fossil fuels burned in the area. The higher ${ }^{14} \mathrm{C}$ enrichment (significant at $95 \%$ confidence level) found for the $\mathrm{CO}_{2}$ sample from SW-2 could be explained because it is closer to the southern mountains, with the dominant wind direction coming from the SSW during the sampling period (Figure 2). These results are in agreement with the high concentrations of retene previously found for this area (AmadorMuñoz et al. 2013).

\section{CONCLUSIONS}

The Mexico City Metropolitan Area is a complex environment, with diverse emission sources, some having high $\Delta^{14} \mathrm{C}$ values, thus making the direct use of ${ }^{14} \mathrm{C}$ to estimate fossil $\mathrm{CO}_{2}$ concentrations in the local atmosphere a difficult task. Temporal variations with annual resolution, as revealed from tree rings, show a significant ${ }^{14} \mathrm{C}$ depletion, with values up to $246 \%$ lower than background ${ }^{14} \mathrm{C}$, in accordance with the vast amount of fossil fuels consumed in the area. On the other hand, $\Delta^{14} \mathrm{C}$ levels for integrated $\mathrm{CO}_{2}$ samples, collected during a warm dry month with frequent forest fires in the mountains surrounding the valley, were up to $27 \%$ higher than the value obtained for a background area for the same sampling year. These results are in agreement with a previous report finding high atmospheric ${ }^{14} \mathrm{C}$ levels for a dry warm period in this complex megacity (Vay et al. 2009).

We believe it is important to continue studying the ${ }^{14} \mathrm{C}$ cycle in this complex urban environment. It is necessary to complete the analyses of tree-ring sequences from both areas to reconstruct annual changes in $\Delta{ }^{14} \mathrm{C}$ and calculate accurately the magnitude of ${ }^{14} \mathrm{C}$ dilution, thus being able to estimate an historical trend of emissions, and find a possible explanation for the lower ${ }^{14} \mathrm{C}$ dilution observed for the last decades. Regarding the $\Delta^{14} \mathrm{C}$ spatial variations, we are currently analyzing samples for the other sampling campaigns, and in the second stage of this project, we are including other tracers, isotopes, and sample types, such as $\mathrm{CO}_{2}$ concentration, soil respiration, and analyses of airborne particulate matter (PM). The analysis, both the isotopic and chemical composition, of PM can help to confirm the influence of biomass burning to the higher-than-background values found for the different areas sampled within the MCMA during April 2013.

Finally, because biomonitoring is an inexpensive and easy way to study temporal and spatial $\Delta^{14} \mathrm{C}$ 
variations, it is important to gain a better knowledge of the $\mathrm{C}$ dynamics in grasses, which would help in establishing an adequate monitoring resolution and the time correspondence to atmospheric ${ }^{14} \mathrm{CO}_{2}$ concentrations, despite the fact that the plants are daytime-only integrated samples.

\section{ACKNOWLEDGMENTS}

This research is funded by DGAPA-UNAM through project PAPIIT-IN106113. Scholarships from CONACyT for AMJ and AMR and from Instituto de Geología and DGAPA-UNAM for AGS are gratefully acknowledged. Personnel from the Stable Isotopes Laboratory, Instituto de Geología, UNAM are thanked for performing $\delta^{13} \mathrm{C}$ analyses on $\mathrm{CO}_{2}$, grass, and plant samples to correct ${ }^{14} \mathrm{C}$ fractionation. Thanks are also due to Dr Retama from Secretaría del Medio Ambiente de la Ciudad de México for granting sampling permission in the SIMAT network, and to the authorities of Chapultepec park for granting permission for sampling tree-ring sequences. Help from technical personnel from SIMAT during the sampling campaigns is gratefully acknowledged. Comments by two anonymous reviewers helped to improve this manuscript.

\section{REFERENCES}

Amador-Muñoz O, Bazán-Torija S, Villa-Ferreira SA, Villalobos-Pietrini R, Bravo-Cabrera JL, MuniveColín Z, Hernández-Mena L, Saldarriaga-Noreña H, Murillo-Tovar MA. 2013. Opposing seasonal trends for polycyclic aromatic hydrocarbons and $\mathrm{PM}_{10}$, health risk and sources in southwest Mexico City. Atmospheric Research 122:199-212.

Beramendi-Orosco LE, González-Hernández G, UrrutiaFucugauchi J, Morton-Bermea O. 2006. The Radiocarbon Laboratory at the National Autonomous University of Mexico: first set of samples and new ${ }^{14} \mathrm{C}$ internal reference material with an activity of 80.4 pMC. Radiocarbon 48(3):485-91.

Beramendi-Orosco LE, Gonzalez-Hernandez G, Villanueva-Diaz J, Santos-Arevalo FJ, Gomez-Martinez I, Cienfuegos-Alvarado E, Morales-Puente P, Urrutia-Fucugauchi J. 2010. Modern radiocarbon levels for northwestern Mexico derived from tree rings - a comparison with Northern Hemisphere zones 2 and 3 curves. Radiocarbon 52(2-3):907-14

Bozhinova D, Combe M, Palstra SWL, Meijer HAJ, Krol MC, Peters W. 2013. The importance of crop growth modeling to interpret the $\Delta^{14} \mathrm{CO}_{2}$ signature of annual plants. Global Biogeochemical Cycles 27(3):792-803.

Bravo JL, Amador-Muñoz O, Villalobos-Pietrini R, Muhlia A. 2006. Influence of some meteorological parameters and forest fires on $\mathrm{PM}_{10}$ concentrations in a Southwest zone of Mexico Valley. International Journal of Environment and Pollution 26(1-3):14255.

CONAFOR (Comisión Nacional Forestal). 2014. Reporte semanal de resultados de incendios forestales 2013. http://www.conafor.gob.mx:8080/ documentos/docs/10/4215Reporte\%20Semanal\%20 2013\%20-\%20Incendios\%20Forestales.pdf. Accessed September 2014.

Escamilla-Herrera I, Santos-Cerquera C. 2012. La Zona Metropolitana del Valle de México: transformación urbano-rural en la región Centro de México. In:
XXII Coloquio Internacional de Geocrítica, Bogota, Colombia, 7-11 May 2012.

Graven HD, Guilderson TP, Keeling RF. 2012. Observations of radiocarbon in $\mathrm{CO}_{2}$ at seven global sampling sites in the Scripps flask network: analysis of spatial gradients and seasonal cycles. Journal of Geophysical Research 117:D02303.

Hua Q, Barbetti M. 2004. Review of tropospheric bomb ${ }^{14} \mathrm{C}$ data for carbon cycle modeling and age calibration purposes. Radiocarbon 46(3):1273-98.

Hua Q, Barbetti M, Rakowski AZ. 2013. Atmospheric radiocarbon for the period 1950-2010. Radiocarbon 55(4):2059-72.

INECC (Instituto Nacional de Ecología y Cambio Climático). 2012. Primer catálogo de estaciones de monitoreo atmosférico en México. http://www2. inecc.gob.mx/publicaciones/consultaPublicacion. html?id_pub=681. Accessed January 2015.

INEGI (Instituto Nacional de Estadística). 2014. México en cifras. http://www3.inegi.org.mx/sistemas/mexicocifras/. Accessed October 2014.

Jauregui E. 2004. Impact of land-use changes on the climate of the Mexico City Region. Investigaciones Geográficas, Boletín del Instituto de Geografía, UNAM 55:46-60.

Kuc T, Rozanski K, Zimnoch M, Necki J, Chmura V, Jelen D. 2007. Two decades of regular observations of ${ }^{14} \mathrm{CO}_{2}$ and ${ }^{13} \mathrm{CO}_{2}$ content in atmospheric carbon dioxide in central Europe: long-term changes of regional anthropogenic fossil $\mathrm{CO}_{2}$ emissions. Radiocarbon 49(2):807-16.

Levin I, Hesshaimer V. 2000. Radiocarbon - a unique tracer of global carbon cycle dynamics. Radiocarbon 42(1):69-80.

Levin I, Munnich KO, Weiss W. 1980. The effect of anthropogenic $\mathrm{CO}_{2}$ and ${ }^{14} \mathrm{C}$ sources on the distribution of ${ }^{14} \mathrm{C}$ in the atmosphere. Radiocarbon 22(2):37991.

Levin I, Kromer B, Schmidt M, Sartorius H. 2003. A novel approach for independent budgeting of fossil 
fuel $\mathrm{CO}_{2}$ over Europe by ${ }^{14} \mathrm{CO}_{2}$ observations. Geophysical Research Letters 30(23):2194.

Levin I, Hammer S, Kromer B, Meinhardt F. 2008. Radiocarbon observations in atmospheric $\mathrm{CO}_{2}$ : determining fossil fuel $\mathrm{CO}_{2}$ over Europe using Jungfraujoch observations as background. Science of the Total Environment 391(2-3):211-6.

Magaña VO, Vázquez JL, Pérez JL, Pérez JB. 2003. Impact of El Niño on precipitation in Mexico. Geofisica Internacional 42(3):313-30.

Molina LT, Madronich S, Gaffney JS, Apel E, de Foy B, Fast J, Ferrare R, Herndon S, Jimenez JL, Lamb B, Osornio-Vargas AR, Russell P, Schauer JJ, Stevens PS, Volkamer R, Zavala M. 2010. An overview of the MILAGRO 2006 Campaign: Mexico City emissions and their transport and transformation. Atmospheric Chemistry and Physics 10:8697-760.

Molnár M, Haszpra L, Svingor É, Major I, Svetlik I. 2010. Atmospheric fossil fuel $\mathrm{CO}_{2}$ measurement using a field unit in a central European city during the winter of 2008/09. Radiocarbon 52(2-3):835-45.

Povinec P, Šivo A, Chudý M, Burchuladze AA, Pagava SV, Togonidze GI, Eristavi IV. 1986. Seasonal variations of anthropogenic radiocarbon in the atmosphere. Nuclear Instruments and Methods in Physics Research B 17(5-6):556-9.

Ramdahl T. 1983. Retene-a molecular marker of wood combustion in ambient air. Nature 306(5943):580-2.

Reimer PJ, Brown TA, Reimer RW. 2004. Discussion: reporting and calibration of post-bomb ${ }^{14} \mathrm{C}$ data. $R a$ diocarbon 46(3):1299-304.

SEDEMA (Secretaría del Medio Ambiente de la Ciudad de México). 2013. Inventario de emisiones contaminantes y de efecto invernadero de la Zona Metropolitana del Valle de México 2012. http://www.sedema. df.gob.mx/flippingbook/inventario-emisioneszmvm2012/. Accessed November 2014

Stahle DW, Villanueva-Diaz J, Burnette DJ, CeranoParedes J, Heim RR, Fye FK, Acuña-Soto R, Therrell MD, Cleaveland MK, Stahle DK. 2011. Major Mesoamerican droughts of the past millennium.
Geophysical Research Letters 38(5):L05703.

Stuiver M, Polach HA. 1977. Discussion: reporting of ${ }^{14} \mathrm{C}$ data. Radiocarbon 19(3):355-63.

Synal HA, Stocker M, Suter M. 2007. MICADAS: a new compact radiocarbon AMS system. Nuclear Instruments and Methods B 259(1):7-13.

Takahashi HA, Konohira E, Hiyama T, Minami M, Nakamura T, Yoshida N. 2002. Diurnal variation of $\mathrm{CO}_{2}$ concentration, $\Delta{ }^{14} \mathrm{C}$ and $\delta^{13} \mathrm{C}$ in an urban forest: estimate of the anthropogenic and biogenic $\mathrm{CO}_{2}$ contributions. Tellus B 54(2):97-109.

Turnbull JC, Miller JB, Lehman SJ, Tans PP, Sparks RJ, Southon J. 2006. Comparison of ${ }^{14} \mathrm{CO}_{2}, \mathrm{CO}$, and $\mathrm{SF}_{6}$ as tracers for recently added fossil fuel $\mathrm{CO}_{2}$ in the atmosphere and implications for biological $\mathrm{CO}_{2}$ exchange. Geophysical Research Letters 33:L01817.

Turnbull JC, Keller ED, Baisden T, Brailsford G, Bromley T, Norris M, Zondervan A. 2014. Atmospheric measurement of point source fossil $\mathrm{CO}_{2}$ emissions. Atmospheric Chemistry and Physics 14:5001-14.

Vay SA, Tyler SC, Choi Y, Blake DR, Blake NJ, Sachse GW, Diskin GS, Singh HB. 2009. Sources and transport of $\Delta^{14} \mathrm{C}$ in $\mathrm{CO}_{2}$ within the Mexico City Basin and vicinity. Atmospheric Chemistry and Physics 9:4973-85.

Villanueva-Díaz J, Stahle DW, Therrel MD, Cleaveland MK, Camacho Morfín F, Núñez Díaz de la Fuente P, Gómez Chávez S, Sánchez Sesma J, Ramírez García JA. 2003. Registros climáticos de los ahuehuetes de Chapultepec en los últimos 450 años. Boletín del Archivo Histórico del Agua 23:34-43.

Wacker L, Nemeç M, Bourquin J. 2010a. A revolutionary graphitisation system: fully automated, compact and simple. Nuclear Instruments and Methods in Physics Research B 268(7-8):931-4.

Wacker L, Christl M, Synal H-A. 2010b. Bats: a new tool for AMS data reduction. Nuclear Instruments and Methods in Physics Research B 268(7-8):976-9.

Zhou W, Wu S, Huo W, Xiong X, Cheng P, Lu X, Niu Z. 2014. Tracing fossil fuel $\mathrm{CO}_{2}$ using $\Delta{ }^{14} \mathrm{C}$ in Xi' an City, China. Atmospheric Environment 94:538-45. 